\title{
INTERFACIAL RECOMBINATION IN InCAIGaAsSb/GaSb THERMOPHOTOVOLTAIC CELLS
}

$$
\text { CONF-981055-- }
$$

V. B. Khalfin, (G. Charache)

October 1998

DISTRIBUTION OF THS DOCUMENT IS UHLMIIED

NOTICE

This report was prepared as an account of work sponsored by the United States Government. Neither the United States, nor the United States Department of Energy, nor any of their employees, nor any of their contractors, subcontractors, or their employees, makes any warranty, express or implied, or assumes any legal liability or responsibility for the accuracy, completeness or usefulness of any information, apparatus, product or process disclosed, or represents that its use would not infringe privately owned rights.

Operated for the U. S. Department of Energy

by KAPL, Inc. a Lockheed Martin company 


\section{DISCLAMMER}

This report was prepared as an account of work sponsored by an agency of the United States Government. Neither the United States Governmeat nor any agency thereof, nor any of their employees, makes any wartanty, express or implied, or assumes any legal liability or responsibility for the accuracy, compieteness, or usefulness of any information, apparatus, product, or process disclosed, or represents that its use would not infringe privately owned rights. Refereace berein to any specific commercial product, process, or service by trade name, trademark, imanufacturer, or otherwise does not necessarily constitute or imply its endorsemeat, recommendation, or favoring by the United States Government or any ageacy thereof. The views and opinions of authors expressed herein do not necessarily state or reflect those of the United States Government or any agency thereof. 


\section{DISCLAIMER}

Portions of this document may be illegible in electronic image products. Images are produced from the best available original document. 


\title{
Interfacial Recombination in in(A) GaAsSb/GaSb Thermophotovoltaic Cells
}

\author{
V. B. Khalfin, D. Z. Garbuzov, H. Lee, G. C. Taylor, N. Morris, \\ R. U. Martinelli, and J. C. Connolly \\ Sarnoff Corporation, CN 5300, Princeton, NJ 08543-5300
}

\begin{abstract}
We have studied efficient p-on-n homo- (InGaAsSb/GaSb) and heterojunction (InGaAsSb/AlGaAsSb/GaSb) thermophotovoltaic (TPV) cells with respect to the recombination velocity at the cap-layer/emitter interface, $S$. In both cell types the open-circuit voltage, $V_{\infty}$, and the shortcircuit current, $J_{*}$, have about the same sensitivity to $S$. The dark current, $J_{o}$ is the most sensitive of all. An examination of the essential factors in the one-dimensional minority-carrier diffusion model shows that under short-circuit conditions, photogenerated electrons diffuse rapidly away from the interface to the junction, whereas under open-circuit conditions, they remain in the emitter for a much longer bulk-recombination time, and therefore, they are more likely to recombine at the interface. A factor of 2.2 increase in $\mathrm{S}$ from 5 to $11 \times 10^{4} \mathrm{~cm} / \mathrm{s}$ produces a $25-\mathrm{mV}$ decrease in $V_{n}$ a $12-\%$ decrease in $J_{x}$ or quantum efficiency, and a factor of two increase in $\mathrm{J}_{0^{-}}$. This work points out the critical importance of interfacial recombination even in efficient TPV cells.
\end{abstract}

\section{Introduction}

We have characterized p-on-n InGaAsSb/GaSb thermophotovoltaic (TPV) cells grown on $\mathrm{GaSb}$ by molecular-beam epitaxy [1,2]. These cells exhibit external spectral quantum efficiencies of $45 \%$ at a wavelength of $1 \mu \mathrm{m}$ and $55 \%$ at 2.25 $\mu \mathrm{m}$, implying internal efficiencies of 82 and $95 \%$, respectively. Using the measured absolute spontaneous emission of forward biased cells, the ratio of the radiative and the Auger recombination coefficients is $1.55 \times 10^{-18} \mathrm{~cm}^{3}$ for cells having p-emitters doped to 1 and $3 \times 10^{1 \kappa} \mathrm{cm}^{-3}[3]$. Optimal p-emitter doping is about $1 \times 10^{1 \mathrm{~B}} \mathrm{~cm}^{3}$, leading to open-circuit voltages of $300 \mathrm{mV}$ at short-circuit current densities of $1 \mathrm{~A} / \mathrm{cm}^{2}$. The ideality factors are near unity, i. e., 1.04. Series resistances for $1 \times 1 \mathrm{~cm}^{2}$ are $9 \mathrm{~m} \Omega \mathrm{cm}^{2}$. Fill factors of $59 \%$ have been measured at current densities of $2.5 \mathrm{~A} / \mathrm{cm}^{2}$. Such operational characteristics show that these devices are well suited for thermophotovoltaic applications. 
This paper discusses an important aspect of the TPV cell's operating characteristics: the different influence of cap-layer/emitter interfacial recombination velocity, $S$, upon the short-circuit current, $J_{\infty}$ i the open-circuit voltage, $\mathrm{V}_{\alpha}$; and upon the dark current density, $\mathrm{J}_{v}$. We show that for efficient cells $a$ change in $S$ from $5 \times 10^{4}$ to $1.1 \times 10^{5} \mathrm{~cm} / \mathrm{s}$ produces a $25-\mathrm{mV}$ drop in $V_{\alpha}$, a $12-\%$ decrease in $I_{\mathrm{x}^{\prime}}$ and a factor of two increase in $J_{n}$.

\section{TPV Cell Architecture}

Figure 1A shows schematically the vertical profile of the 0.55-eV TPV cell, and Fig. $1 B$ shows the front-surface metallization configuration.

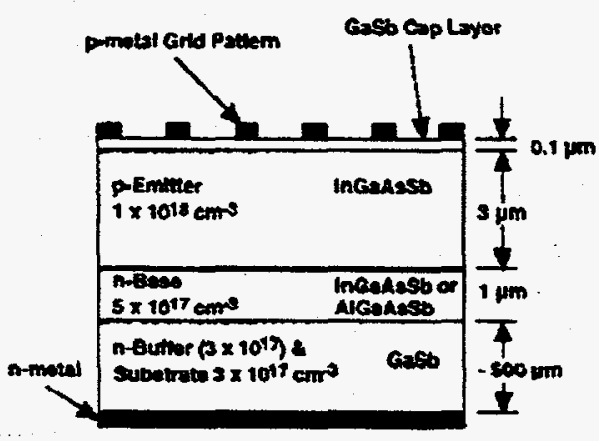

(A)

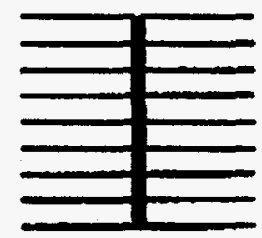

(B)

Figure 1. (A) The vertical profile of the TPV cells. (B) TPV Cell front-surface metallization pattern.

A 1-pm-thick $\mathrm{n}$-GaSb (Te-doped to $3 \times 10^{17} \mathrm{~cm}^{3}$ ) buffer layer is grown on the substrate, followed by the active layers of the cell. The $\mathrm{n}-\mathrm{Al}_{\mathrm{n}, 25} \mathrm{Ga}_{0,55} \mathrm{As}_{0,02} \mathrm{Sb}_{0.9}$ or $\mathbf{n}$ $I n_{n, 16} \mathrm{Ga}_{0.84} \mathrm{As}_{0.04} \mathrm{Sb}_{0.06}$ base thickness is $1 \mu \mathrm{m}$ (Te-doped to $5 \times 10^{17} \mathrm{~cm}^{-3}$ ). The 3- $\mu \mathrm{m}-$ thick p- $\mathrm{In}_{0.16} \mathrm{Ga}_{0.0} \mathrm{As}_{0.0} \mathrm{Sb}_{0.06}$ emitter is Be-doped to $1 \times 10^{18} \mathrm{~cm}^{3}$. Homo- and hetero-junction structures were used in the interfacial recombination-velocity studies. Owing to the relatively wider bandgap of $0.95 \mathrm{eV}$ of the $\mathrm{n}$ $\mathrm{Al}_{0.25} \mathrm{Ga}_{0,25} \mathrm{As}_{0,02} \mathrm{Sb}_{0,9}$ base and depletion region, recombination occurs predominantly in the $\mathrm{p}-\mathrm{In}_{0.16} \mathrm{Ga}_{0.4} \mathrm{As}_{0, \Omega} \mathrm{Sb}_{0.9}$ emitter, thus facilitating the interpretation of experimental results. Both cell types exhibit comparable quantum efficiencies at high excitation levels.

Finally, a thin cap layer of p-GaSb is grown on the emitter. This layer provides a conduction-band barrier at the cell input surface that reduces the effective recombination velocity at the cap-layer/emitter interface, while absorbing little radiation. Initial devices incorporated a $0.05-\mu m$-thick cap, Be-doped to $1 \times 10^{10}$ $\mathrm{cm}^{-3}$. During processing, we discovered that the photoresist developer etches the GaSb cap layer at a rate of $20 \mathrm{~nm} / \mathrm{min}$. The estimated thickness of the etched cap-layer is 20 to $30 \mathrm{~nm}$, leaving open the possibility of electron tunneling to the 
free GaSb surface. To avoid creating such a thin a cap layer, an additional $0.1 \mu \mathrm{m}$ of GaSb was regrown on the cap layer, creating a cap layer $0.15 \mu \mathrm{m}$ thick. During processing, 20 to $30 \mathrm{~nm}$ was etched, so that the final thickness was 0.12 to $0.13 \mu \mathrm{m}$. In some cases the first $0.05 \mu \mathrm{m}$ of GaSb was doped to $2 \times 10^{\text {th }} \mathrm{cm}^{-3}$, and the remaining $0.05 \mu \mathrm{m}$ was doped to $1 \times 10^{19} \mathrm{~cm}^{-3}$, producing a built-in electric field that sweeps photogenerated electrons into the emitter. The characteristics of cells with thin $(20-30 \mathrm{~nm})$ cap layers and ones with thick $(0.12-0.13 \mu \mathrm{m})$ cap layers, some of which contained a built-in field, were studied to determine the influence of interfacial recombination on $J_{x^{\prime}}, V_{x^{\prime}}$, and $J_{0}$.

The front surface metallization pattem is an array of 10- $\mu \mathrm{m}$-wide fingers on 100$\mu \mathrm{m}$ centers. The fingers emanate from a central 200- $\mu \mathrm{m}$-wide busbar. The metallization was e-beam deposited $\mathrm{Ti}(10 \mathrm{~nm}) / \mathrm{Au}(100 \mathrm{~nm}) / \mathrm{Pt}(100 \mathrm{~nm}) /$ Au( $50 \mathrm{~nm})$, followed by $5-\mu \mathrm{m}$ of plated Au. This metallization pattern was applied to $4 \times 4 \mathrm{~mm}^{2}$ cells and to $1 \times 1 \mathrm{~cm}^{2}$ cells. The substrate metallization was $\mathrm{Ni}(5 \mathrm{~nm}) / \mathrm{Au}(45 \mathrm{~nm}) / \mathrm{Ge}(20 \mathrm{~nm}) / \mathrm{Ni}(15 \mathrm{~nm}) / \mathrm{Au}(20 \mathrm{~nm})$. The cells were Insoldered to copper submounts for testing at $15^{\circ} \mathrm{C}$.

\section{The Influence of Cap-Layer/Emitter Recombination on $J_{s e}$ and $V_{o c}$}

Figure 2 shows the semilogarithmic $I_{*}-V_{\alpha}$ characteristics of two $4 \times 4 \mathrm{~mm}^{2}$ heterojunction cells, one with the thin GaSb cap layer and one with the thick cap layer without a built-in field. 


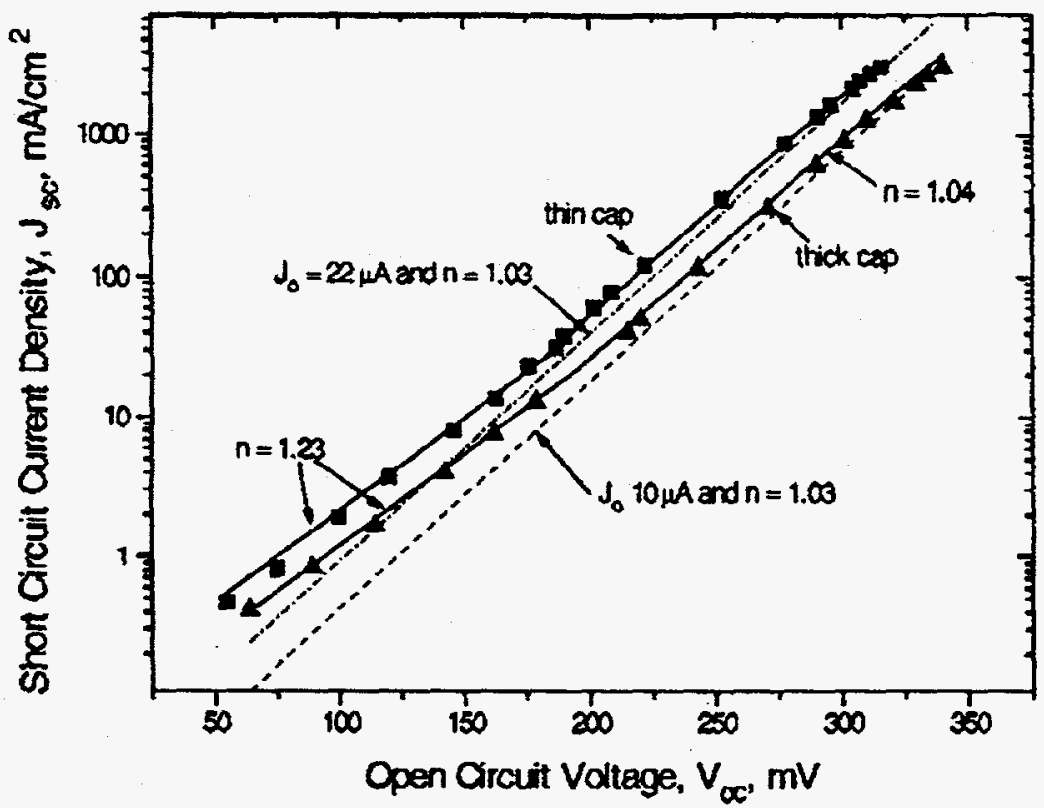

Figure 2. Short:circuit current density and open-circuit voltage of two heterojunction TPV cells: one with the original Gasb etched cap layer (thin) and one with a regrown GaSb cap layer (thick).

Both cells were made from the same wafer. Short-circuit current densities from 0.5 to $3000 \mathrm{~mA} / \mathrm{cm}^{2}$ were generated in each cell, and the corresponding values of $\mathrm{V}_{\alpha}$ were measured. We assume the data to be described by the usual exponential dependence of $J_{k}$ on $V_{\alpha}: J_{\kappa}=J_{0} \exp \left(V_{\alpha} / n k T\right)$, where $J_{0}$ is the dark-current-density parameter, $\mathbf{n}$ is the ideality factor, and $\mathrm{kT}$ is the thermal energy measured in $\mathrm{eV}$. Each characteristic has two branches: one with an ideality close to 1.2 at excitation levels less than about $100 \mathrm{~mA} / \mathrm{cm}^{2}$, and the other with an ideality factor close to 1.0 at excitation levels higher than $100 \mathrm{~mA} / \mathrm{cm}^{2}$. The low-levelexcitation branches presumably arise from recombination in the depletion region; those at high-excitation levels arise from recombination in the emitter bulk and cap-layer/emitter interface. Model fits to the four highest data points of each characteristic are also shown, as dashed and dot-dashed lines, along with the values of $J_{0}$ and $n$ used; these fitted curves will be discussed below. At a given value of $J_{\alpha,}, V_{\alpha}$ for the cell with the thick cap layer is 20 to $25 \mathrm{mV}$ higher than the thin-cap-layer cell.

Figure 3 shows $J_{k}$ for both cells as a function of the illumination level, $P$, in arbitrary units. 


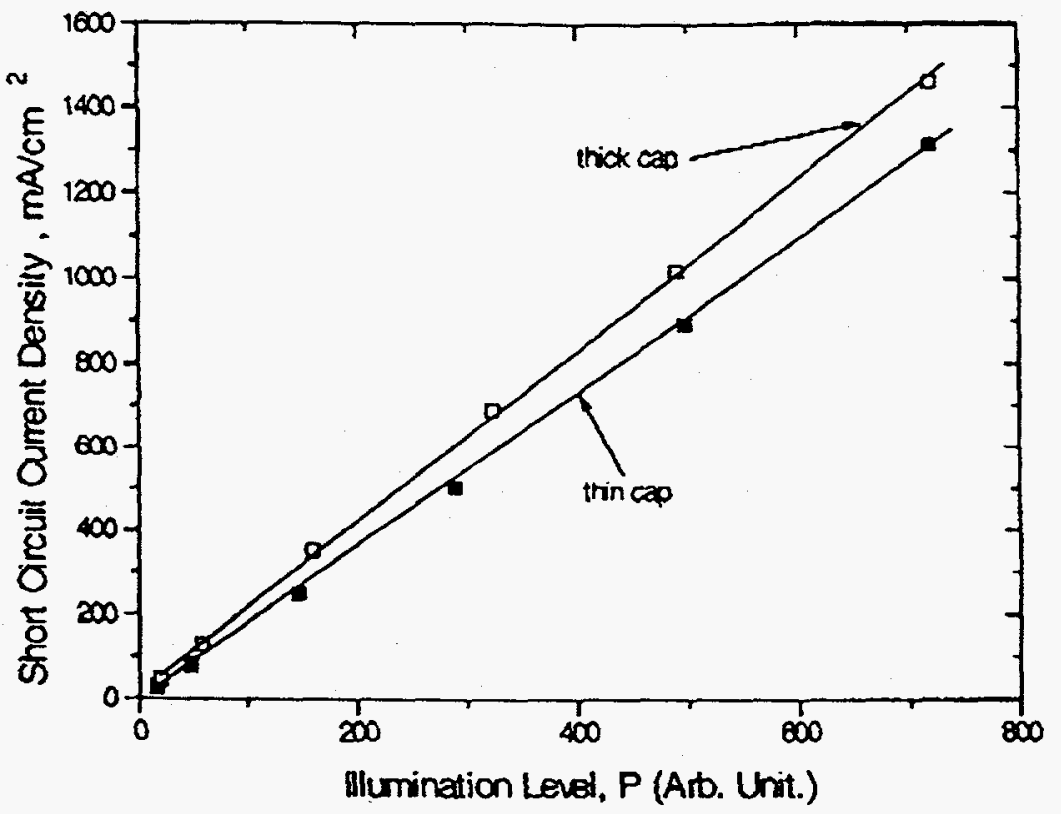

Figure 3. Short-circuit current density photoresponse for two heterojunction TPV cells: one with the original GaSb etched cap layer (thin) and one with a regrown GaSb cap layer (thick).

$\mathrm{J}_{\mathrm{sc}}$ is proportional to the quantum efficiency. The curves are linear, and at the highest excitation level, the difference in $J_{x}$ for the two cells is $12 \%$.

The thick GaSb cap layer reduces the cap-layer/emitter recombination velocity, $S$. For a given excitation level, $J_{\alpha}$ and $V_{\alpha}$ increase in cells with a thick cap layer, and $J_{0}$ decreases. To calculate these effects, we use the simple one-dimensional diffusion model to describe minority-carrier dynamics in the emitter [4]. The cells have high quantum efficiencies, implying that the electron diffusion length, $L$, is much longer than the emitter width, W; and that $S$ is not much different from the natural bulk recombination velocity, $D / L$, in which $D$ is the electron diffusion constant. Also, we assume that the absorption length of the exciting radiation, $\alpha^{-1}$, is much shorter than $L$.

Eliminating all extraneous prefactors, the dependence of $J_{x}$ on $S$ is given by

$$
\mathrm{J}_{*} \propto \frac{\alpha \mathrm{L}+\mathrm{S} /(\mathrm{D} / \mathrm{L})}{\alpha \mathrm{L}-1} \frac{1}{1+\mathrm{S} /(\mathrm{D} / \mathrm{W})}
$$

and with our assumptions that 


$$
\begin{aligned}
\alpha \mathrm{L}, & >1 \text { and } \mathrm{S} /(\mathrm{D} / \mathrm{L}) \sim 1 \\
\mathrm{~J}_{*} & \equiv \frac{1}{1+\mathrm{S} /(\mathrm{D} / \mathrm{W})} \equiv \frac{1}{1+\mathrm{C}_{\mathrm{wc}}}
\end{aligned}
$$

$C_{\mathrm{sz}}$ defines the factor $\mathrm{S} /(\mathrm{D} / \mathrm{W})$, through which $\mathrm{J}_{\mathrm{sc}}$ depends on $\mathrm{S}$.

In a similar way, the dependence of $V_{u c}$ on $S$ can be obtained. $V_{o x}$ is a logarithmic function of $\mathrm{N}_{0}$, the photogenerated electron concentration in the emitter:

$$
\mathrm{V}_{\mathrm{c}}=\mathrm{kT} \ln \left(\mathrm{N}_{\mathrm{o}} / \mathrm{n}_{\mathrm{p}}\right)
$$

where $n_{p}$ is the background electron concentration in the p-type emitter. The dependence of $N_{0}$ on $S$ is given by

$$
\mathrm{N}_{0} \propto \frac{\alpha \mathrm{L}+\mathrm{S} /(\mathrm{D} / \mathrm{L})}{\alpha \mathrm{L}-1} \frac{1}{1+\mathrm{SL}^{2} / \mathrm{DW}} \equiv \frac{1}{1+\mathrm{SL}^{2} / \mathrm{DW}} \equiv \frac{1}{1+\mathrm{C}_{\mathrm{q}}}
$$

and the factor $C_{x x}=S L^{2} /(D W)$ has been defined. The ratio of $C_{x c}$ to $C_{x}$ is much less than unity, showing that $N_{0}$ is more sensitive to $S$ than is $J_{x}$ :

$$
\frac{C_{x c}}{C_{\infty}}=\frac{W^{2}}{L^{2}} \ll<1
$$

Another way to view this effect is to compare the time constants associated with $\mathrm{J}_{\mathrm{x}}$ and $\mathrm{N}_{\mathrm{v}}$. The time constant associated with $\mathrm{J}_{\mathrm{x}}$ is the diffusion time of electrons out of the emitter, $\tau_{\mathrm{p}}$ which is given by

$$
\tau_{D}=W^{2} / D
$$

The time constant associated with $N_{0}$ is the bulk recombination time $\tau$, given by

$$
\tau=L^{2} / D
$$

Thus, the ratio of these two time constants equals $C_{x} / C_{o x}$ and is much less than unity:

$$
\tau_{13} / \tau=C_{\alpha c} / C_{\alpha c}=W^{2} / L^{2} \ll 1
$$


$J_{\kappa}$ is less sensitive to $S$ than $N_{0}$ because under short-circuit conditions, photogenerated electrons quickly diffuse out of the emitter. On the other hand, photogenerated electrons under open-circuit conditions linger in the emitter for the much longer bulk-recombination time, thereby increasing their chance to recombine at the cap-layer/emitter interface.

Figure 4 shows the calculated relative decrease of $J_{x}$ with increasing $S$, and Fig. 5 shows the decrease in $V_{\alpha}$ with increasing $S$.

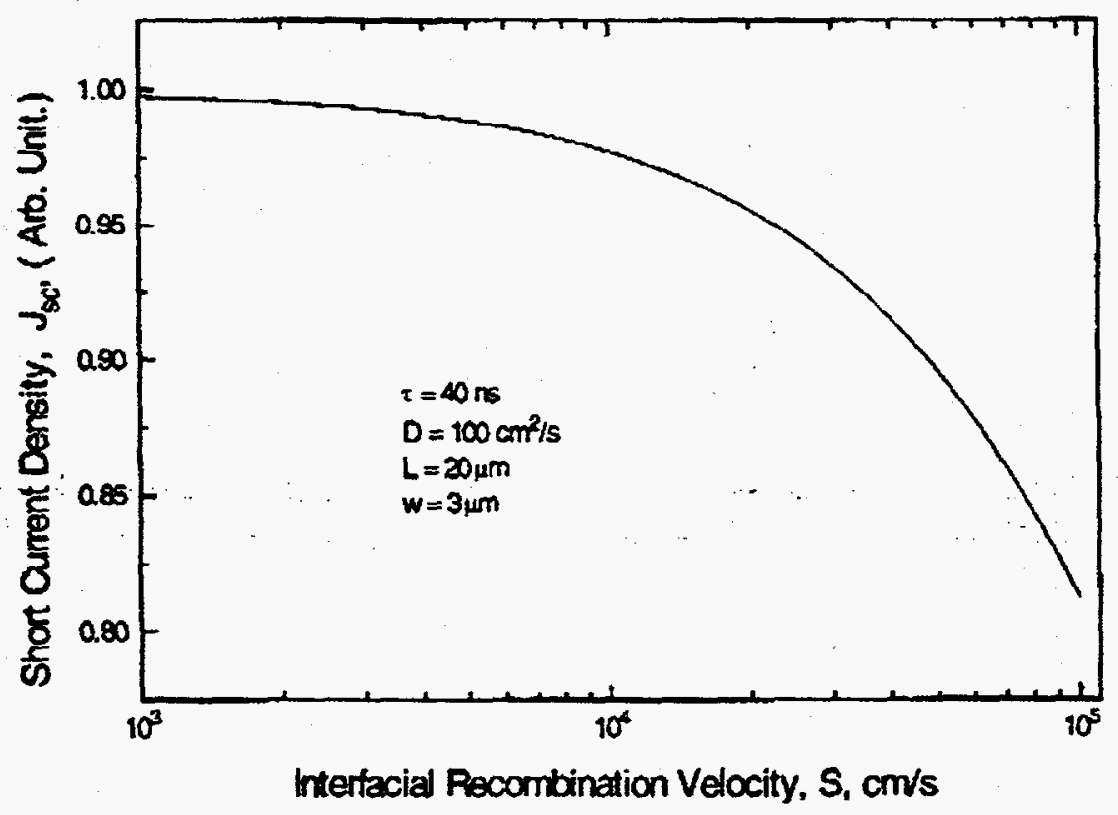

Figure 4. The calculated relative decrease in the short-circuit current with increasing cap-layer/emitter interfacial recombination velocity. 


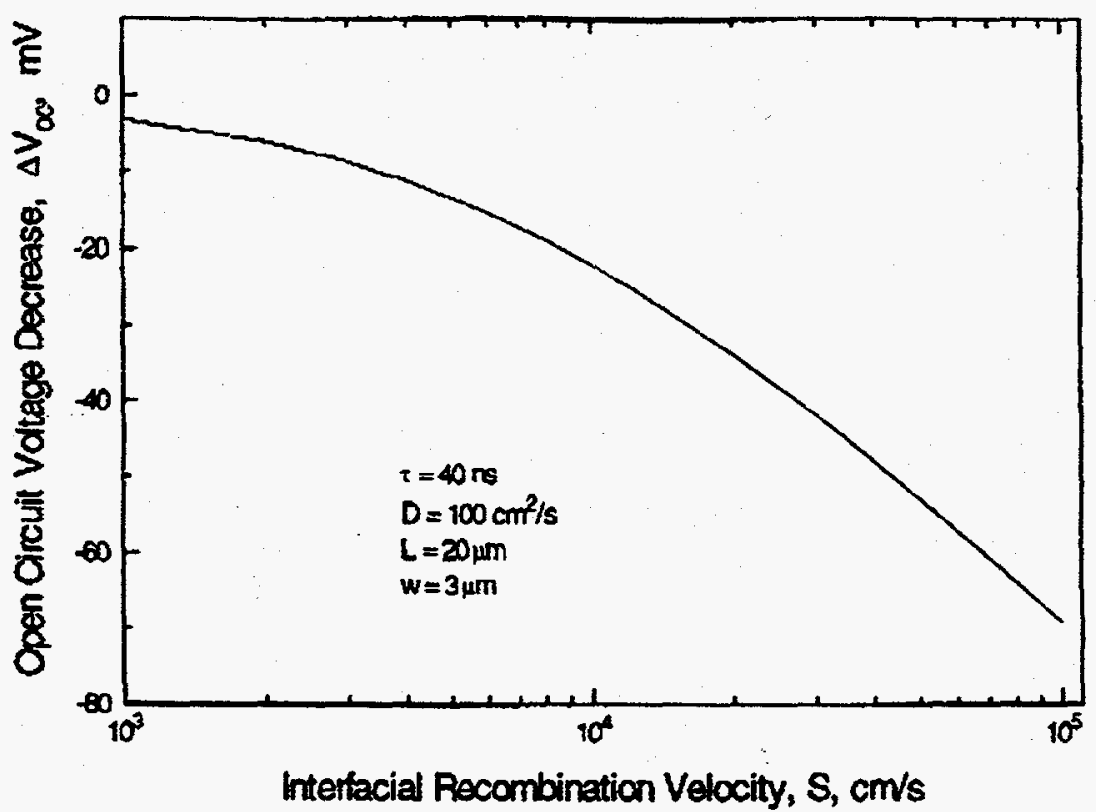

Figure 5. The calculated decrease in open-circuit voltage with increasing cap-layer/emitter interfacial recombination velocity.

These curves were calculated using the one-dimensional diffusion model. The parameter values were $W=3 \mu \mathrm{m}, \tau=40 \mathrm{~ns}, D=100 \mathrm{~cm}^{2} / \mathrm{s}$, giving $\mathrm{L}=20 \mu \mathrm{m}, \tau_{\mathrm{p}}=$ 0.9 ns. $\mathrm{D} / \mathrm{L}=5 \times 10^{4} \mathrm{~cm} / \mathrm{s}$. The difference in $\mathrm{V}_{\alpha}$ is shown because $\mathrm{V}_{\alpha}$ depends logarithmically on $N_{0}$ and it is the ratio of $N_{0}$ values that is compared.

Increasing $S$ from $10^{3}$ to $10^{3} \mathrm{~cm} / \mathrm{s}$ produces a $20-\%$ decrease in Isc $_{\text {(Fig. } 4 \text { ) and a } 70-}$ meV drop in $V_{\alpha}$ (Fig. 5).

For our range of parameters, the simplified diffusion model also gives the expression for the dependence of the dark current density, $\mathrm{J}_{0}$, on $\mathrm{S}$ :

$$
J_{0}=A \frac{S /(D / L)+W / L}{S /(D / W)+1} \equiv A \frac{S}{(D / L)}
$$

$\mathrm{J}_{0}$ is directly proportional to $\mathrm{S}$, and $\mathrm{A}$ is a constant of proportionality.

Returning to the fitted curves in Fig. 2, the value of $\mathrm{J}_{0}$ for the cell with the thick cap layer is $10 \mu \mathrm{A}$, and if we assume $\mathrm{S}=5 \times 10^{4} \mathrm{~cm} / \mathrm{s}(i . e ., \mathrm{S} /(\mathrm{D} / \mathrm{L})=1) \mathrm{A}=10$ $\mu \mathrm{A}$. For the cell with the thin cap layer the value of $J_{0}$ is $22 \mu \mathrm{A}$, which, since $A$ is a constant, implies that $S=1.1 \times 10^{5} \mathrm{~cm} / \mathrm{s}$. As can be seen from Fig. 4, the corresponding calculated decrease in $\mathrm{J}_{\kappa}$ is about $10 \%$, which is in reasonable 
agreement with the 12-\% decrease for the highest data points shown in Fig. 3. Likewise, from Fig. 5 the calculated decrease in $\mathrm{V}_{\kappa}$ is $20 \mathrm{mV}$, again in reasonable agreement with the $25 \mathrm{mV}$ difference in the highest data points shown in Fig. 2 . For both cells the values of $S /(D / L)$ are close to unity. We see experimentally that as $\mathrm{S}$ increases by a factor of $2.2, \mathrm{~J}_{\alpha}$ decreases by $12 \%, \mathrm{~V}_{\alpha}$ decrease by $25 \mathrm{mV}$, and $\mathrm{J}_{0}$ increases by a factor of two.

Similar results are obtained for homojunction TPV cells. Figure 6 shows the $J_{x}$ $\mathrm{V}_{\alpha}$ characteristics of two $4 \times 4 \mathrm{~mm}^{2}$ homojunction cells.

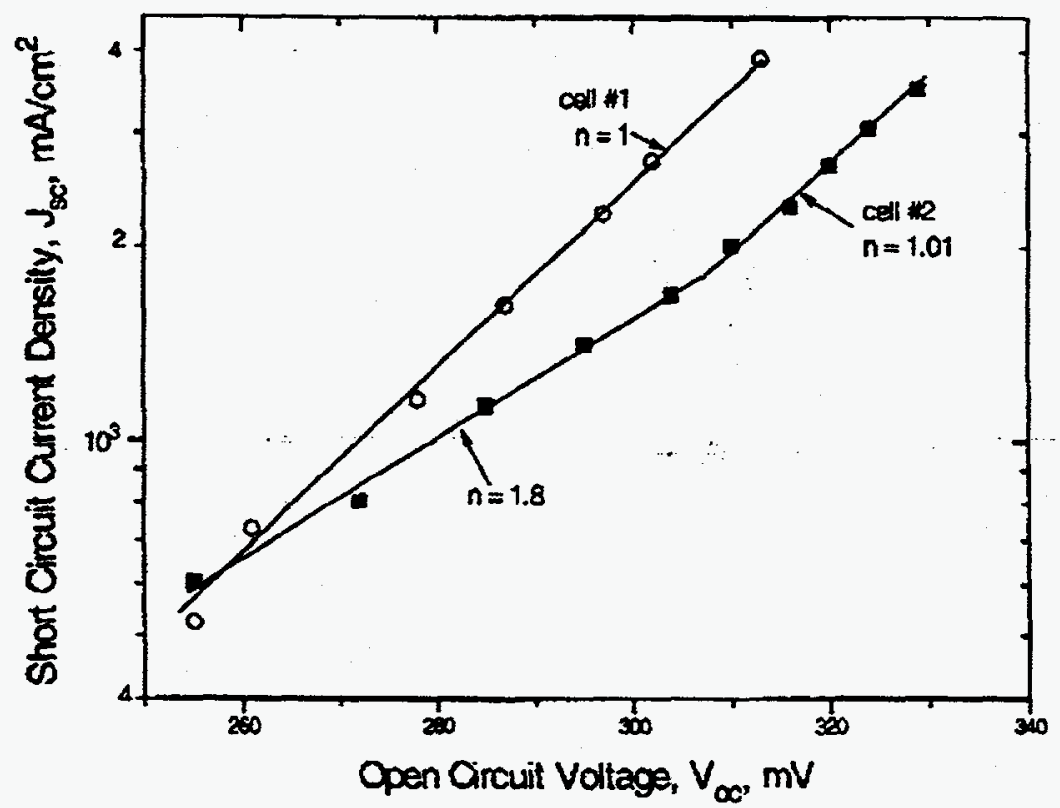

Figure 6. $J_{s c}-V_{o c}$ characteristics of two homojunction TPV cells: one with a thin cap layer, cell $\# 1$, and one with a thick cap layer, cell \#2.

Cell \#1 has a thin cap layer, and cell \#2 has a thick cap layer containing a built-in field. At short-circuit current densities approaching $3 \mathrm{~A} / \mathrm{cm}^{2}$ cell \#2 produces a $15-\mathrm{mV}$ larger open-circuit voltage than does cell \#1. We interpret this increase as a decrease in $S$. The lower value of $S$ reduces $J_{0}$ by about a factor of two from 500 to $250 \mathrm{~mA} / \mathrm{cm}^{2}$. As was the case for heterojunction cells, a thick GaSb cap layer reduces $S$ by a factor of two.

At excitation levels below $2000 \mathrm{~mA} / \mathrm{cm}^{2}$, depletion-layer recombination in cell \#2 is evidenced by the branch in its characteristic with an ideality factor of $n=1.8$. Note that this is larger than that of the heterojunction cells, in which $n=1.2$ (Fig. 
2), indicating the stronger depletion-region recombination in the homojunction cells.

\section{Summary and Conclusions}

Efficient p-on-n homo- (InGaAsSb/GaSb) and hetero-junction (InGaAsSb/AlGaAsSb/GaSb) thermophotovoltaic (TPV) cells were studied with respect to the recombination velocity at the cap-layer/emitter interface, S. In both cell types the open-circuit voltage, $V_{\alpha x}$ and the short-circuit current, $I_{e v}$ each have about the same sensitivity to $S$. The dark current, $J_{0}$, is much more sensitive to $S$. An examination of the essential factors in the one-dimensional minoritycarrier diffusion model shows that under short-circuit conditions, photogenerated electrons diffuse rapidly away from the interface to the junction. Under open-circuit conditions, the electrons remain in the emitter for a much longer bulk-recombination time, and therefore, they are more likely to recombine at the interface. $J_{v}$ is proportional to $S$. An increase in $S$ from $5 \times 10^{4}$ to $1.1 \times 10^{5}$ $\mathrm{cm} / \mathrm{s}$ produces a $25 \mathrm{mV}$ decrease in $V_{\alpha}$ and a $12-\%$ decrease in $J_{\kappa}$ or quantum efficiency. $J_{0}$ increases by a factor of two. This work points out the critical importance of interfacial recombination even in efficient TPV cells.

\section{References}

1. R. U. Martinelli, D. Z. Garbuzov, H. Lee, N. Morris, T. Odubanjo, G. C. Taylor, and J. C. Connolly, "The Quantum Efficiency of InGaAsSb Thermophotovoltaic Diodes", in Space Technology and Applications International Forum - 1998, edited by M. S. El-Genk, AIP Conf. Proc. 420, pp 1394 - 1399 (1998)

2. D. Z. Garbuzov, R. U. Martinelli, V. B. Khalfin, H. Lee, N. Morris, G. C. Taylor, J. C. Connolly, G. W. Charache, and D. M. Dupoy, "A Novel Approach for the Improvement of Open Circuit voltage and Fill Factor of InGaAsSb/GaSb Thermophotovoltaic Cells", in Space Technology and Applications International Forum - 1998, edited by M. S. El-Genk, AlP Conf. Proc. 420, pp 1400 - 1409 (1998)

3. G. W. Charache, P. F. Baldasaro, L. R. Danielson, D. M. Dupoy, M. J. Freeman, C. A. Wang, H. K. Choi, D. Z. Garbuzov, R. U. Martinelli, V. Khalfin, S. Saroop, J. M. Borrego, and R. J. Gutmann, "InGaAsSb Thermophotovoltaic Diode Physics Evaluation", presented at the Fortieth Electron Materials Conference, June $24-26,1998$, Charlottesville, VA. Also submitted to the J. Appl. Phys. for publication. 
4. S. M. Sze, "Physics of Semiconductor Devices" $2^{\text {mt }}$ ed., John Wiley and Sons, New York, 1981, 802-805. 